\title{
Metastatic rectal adenocarcinoma within haemorrhoids: a case
} report

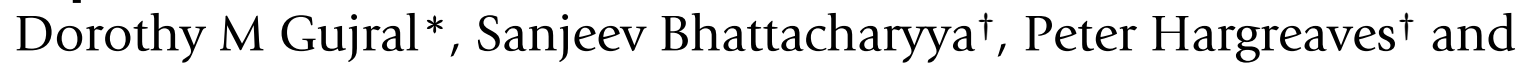 \\ Gary W Middleton ${ }^{\dagger}$
}

Address: St Lukes Cancer Centre, Royal Surrey County Hospital, Egerton Road, Guildford, Surrey GU2 7XX, UK

Email: Dorothy M Gujral* - gjrdor001@yahoo.com; Sanjeev Bhattacharyya - sanjeev144@hotmail.com; Peter Hargreaves - peter.hargreaves@wsx-pct.nhs.uk; Gary W Middleton - gmiddleton@ royalsurrey.nhs.uk

${ }^{*}$ Corresponding author †Equal contributors

\author{
$\begin{array}{ll}\text { Published: } 28 \text { April } 2008 & \text { Received: } 2 \text { November } 2007\end{array}$ \\ Journal of Medical Case Reports 2008, 2:128 doi:10.1 186/1752-1947-2-128 \\ Accepted: 28 April 2008 \\ This article is available from: http://www.jmedicalcasereports.com/content/2/1/128 \\ (c) 2008 Gujral et al; licensee BioMed Central Ltd. \\ This is an Open Access article distributed under the terms of the Creative Commons Attribution License (http://creativecommons.org/licenses/by/2.0), \\ which permits unrestricted use, distribution, and reproduction in any medium, provided the original work is properly cited.
}

\begin{abstract}
Introduction: Metastatic tumour involvement of the anal canal is rare. Routine pathological evaluation of haemorrhoidectomy specimens has been suggested to be unhelpful and expensive. Selective rather than routine pathological evaluation of haemorrhoidectomy specimens has been recommended.
\end{abstract}

Case presentation: We report the case of a 69 -year-old woman with metastatic colorectal carcinoma who presented with metastatic carcinoma within thrombosed haemorrhoids.

Conclusion: We suggest that in patients with colorectal cancer, careful examination of haemorrhoids on colonoscopy as well as histological examination of suspected haemorrhoidal tissue after surgical resection be performed to evaluate for metastasis.

\section{Introduction}

Metastatic tumour involvement of the anal canal is rare. There have been around 200 cases of metastatic anorectal melanoma, with the first case described in 1857 by Moore [1]. Other non-colorectal tumours in the anal canal are very rare. Metastatic tumour involvement of the anal canal from squamous cell carcinoma, anaplastic carcinoma of the lung and breast cancer has previously been reported [2-4]. Metastatic cancer to haemorrhoidal tissue is even rarer $[5,6]$.

Lemarchand et al. [7] performed a retrospective analysis of haemorrhoidectomy specimens obtained in a coloproctology unit between 1 January 1985 and 31 December 2001. Fifty-six histological abnormalities (0.69\%) were detected among 8153 haemorrhoidectomy speci- mens considered normal at gross macroscopic examination. The authors concluded that routine pathological evaluation of haemorrhoidectomy specimens was not useful and was expensive. The authors also concluded that selection for gross and microscopic evaluation of suspicious areas at the preoperative examination should be continued.

A study by Cataldo et al. [8] looked at haemorrhoidectomy specimens taken from 21,257 patients over a 20 year period. They noted only one instance of unsuspected carcinoma of the anus diagnosed solely by microscopic analysis of a specimen that was taken at haemorrhoidectomy, and the authors recommended selective rather than routine pathological evaluation of haemorrhoidectomy specimens. It would be reasonable to assume that patients 


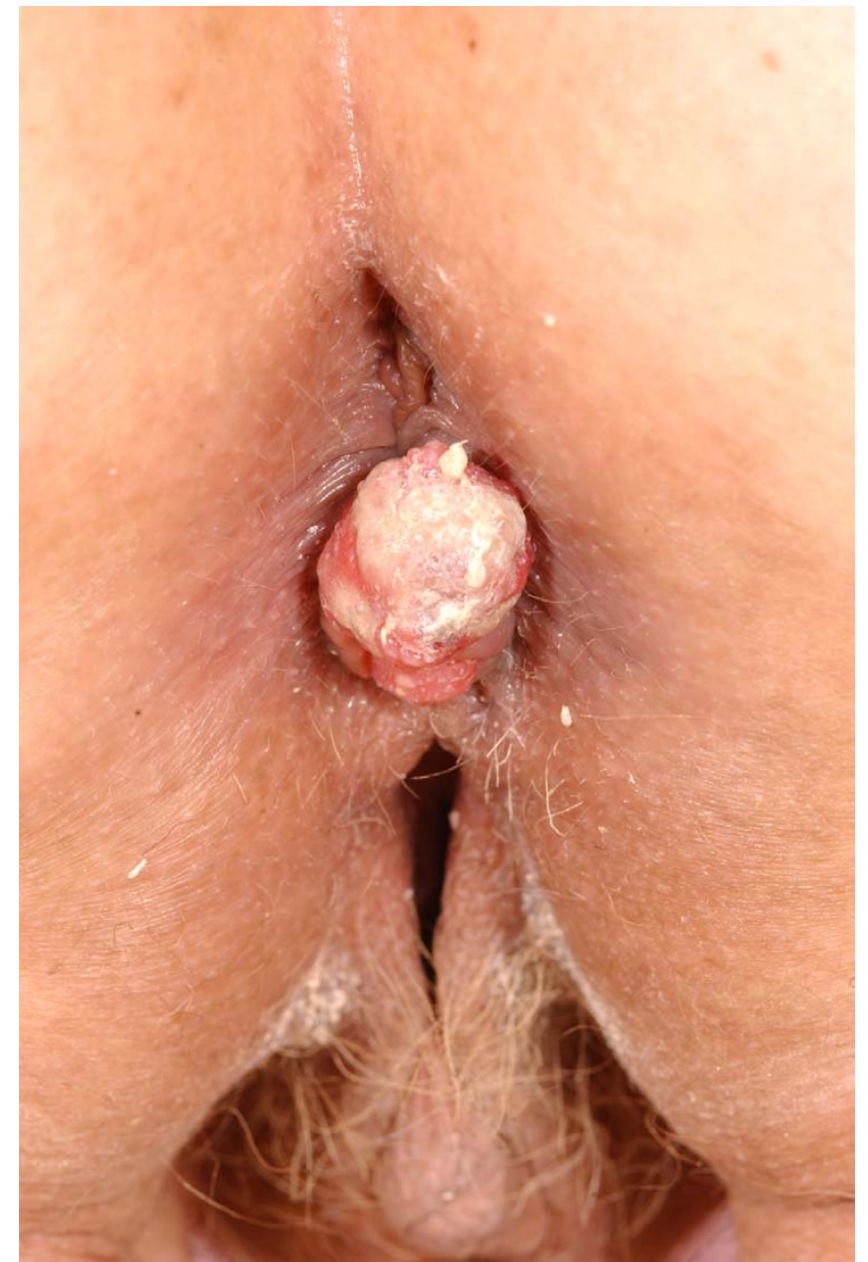

Figure I

Pedunculated, hard, ulcerating haemorrhoids with tumour deposits.

with known carcinoma would be at higher risk of developing haemorrhoidal metastases.

\section{Case presentation}

A 69-year-old woman presented in February 2003 with a 6 -week history of progressive change in bowel habit. She had noticed fresh blood mixed with her stools, a 1-stone weight loss, and pelvic pain.

Blood tests showed an elevated carcino-embryonic antigen (CEA) of $560 \mathrm{ng} / \mathrm{ml}$ and colonoscopy revealed a fixed, circumferential rectal carcinoma at $6 \mathrm{~cm}$. No other synchronous tumours were noted to the level of the caecum. Computed tomography scan showed bilateral pulmonary metastases, multiple liver metastases, and a large mass in the recto-sigmoid region consistent with known carcinoma. Magnetic resonance imaging of the pelvis confirmed a large infiltrative tumour seen in the upper rectum

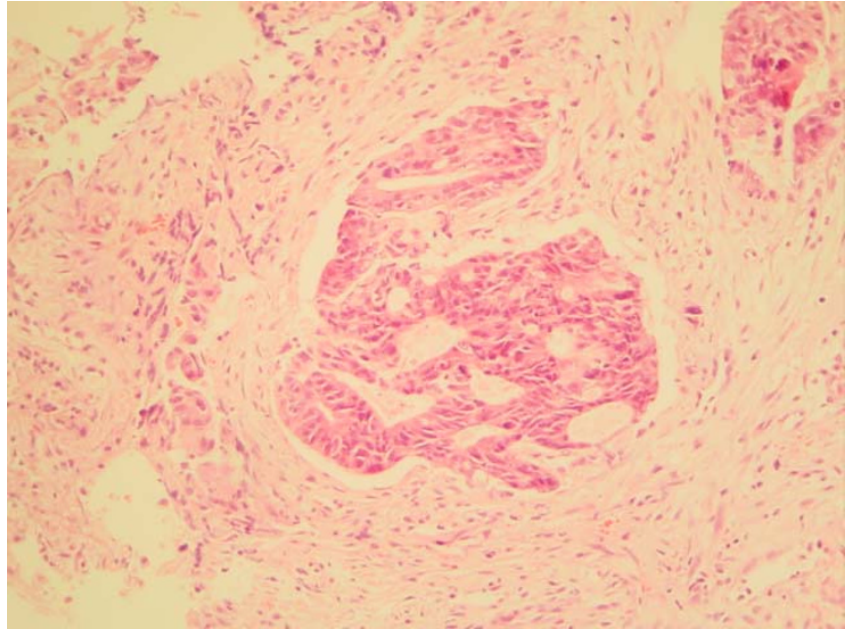

Figure 2

Original biopsy of rectal tumour demonstrating adenocarcinoma.

with ill-defined margins. Rectal biopsy confirmed a moderate to poorly differentiated adenocarcinoma of large bowel type.

The patient was commenced on palliative chemotherapy with irinotecan and infusional 5-FU. After 14 cycles, the patient unfortunately developed progressive disease with new pulmonary metastases and an increase in the size of her liver metastases as well as an increase in her CEA from $113 \mathrm{ng} / \mathrm{ml}$ to $710 \mathrm{ng} / \mathrm{ml}$. Consequently, in January 2004, treatment was changed to oxaliplatin and infusional 5-FU chemotherapy.

After three cycles, the patient presented complaining of prolapsed 'piles' and on examination was found to have pedunculated, hard and ulcerating haemorrhoids. Tumour deposits were noted at the 6 and 12 o'clock positions (Figure 1). These were subsequently excised and microscopy revealed deposits of moderate to poorly differentiated adenocarcinoma of large bowel type similar to the original rectal biopsy (Figures 2 and 3).

\section{Conclusion}

This case is, to the best of our knowledge, the first case that demonstrates bowel adenocarcinoma deposits within haemorrhoids. We suggest that in patients with a history of colorectal cancer, careful examination of haemorrhoids during colonoscopy, as well as histological examination of suspected haemorrhoidal tissue after surgical resection, be performed to evaluate for the possible presence of metastasis. 


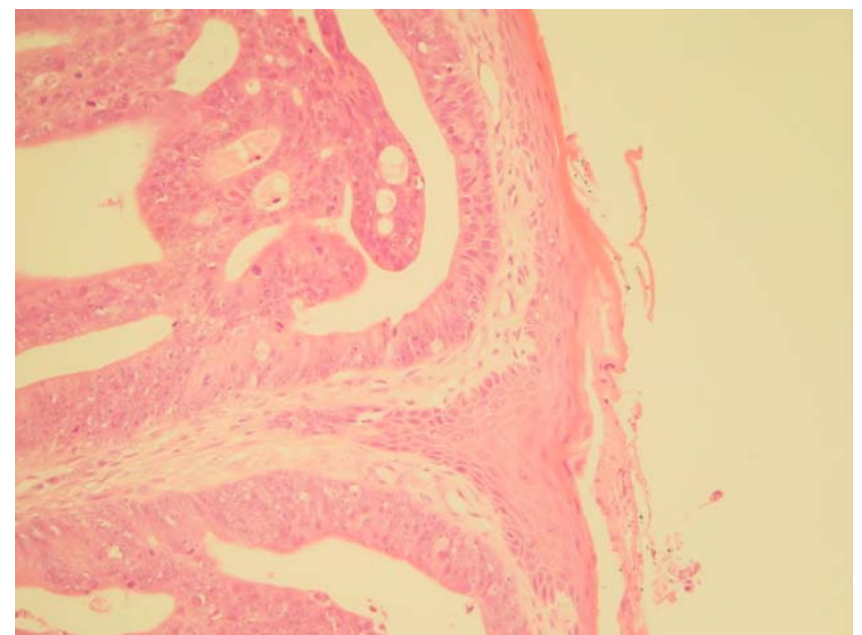

Figure 3

Biopsy of haemorrhoidectomy specimen with adenocarcinoma within anal canal squamous tissue.

\section{Competing interests}

The authors declare that they have no competing interests.

\section{Authors' contributions}

DMG, PH and GWM were all involved in the clinical care of the patient. DMG, SB and PH conceived, researched, wrote the paper and revised the final manuscript. All authors read and approved the final manuscript.

\section{Consent}

Written consent was obtained from the patient's next-ofkin for publication of this case report and accompanying images. A copy of the written consent is available for review by the Editor-in-Chief of this journal.

\section{References}

I. Moore : Recurrent melanomas of the rectum, after previous removal from the verge of the anus, in a man age sixty-five. Lancet I857, I:290.

2. Rueben J, Ger R: Squamous cell carcinoma of the anal canal: a metastatic lesion. Dis Colon Rectum 1968, I I:2 13-219.

3. Kanhouwa S, Burns W, Matthews M, Chisholm R: Anaplastic carcinoma of the lung with metastasis to the anus: report of a case. Dis Colon Rectum 1975, I 8:42-48.

4. Dawson PM, Hershman MJ, Wood CB: Metastatic carcinoma of the breast in the anal canal. Postgrad Med J 1985, 6I:I08I.

5. Sawh RN, Borkowski J, Broaddus R: Metastatic renal cell carcinoma presenting as a haemorrhoid. Arch Pathol Lab Med 2002, I 26:856-858.

6. Timaran CH, Sangwan YP, Solla JA: Adenocarcinoma in a haemorrhoidectomy specimen: case report and review of the literature. Am Surg 2000, 66:789-792.

7. Lemarchand N, Tanne F, Aubert M, Benfredj P, Denis J, DuboisAmous N, Fellous K, Ganansia R, Senejoux A, Soudan D, Puy-Montbrun $\mathrm{T}$ : Is routine pathologic evaluation of haemorrhoidectomy specimens necessary? Gastroenterol Clin Biol 2005, 29:213-217.

8. Cataldo PA, Mackiegan JM: The necessity of routine pathologic evaluation of haemorrhoidectomy specimens. Surg Gynecol Obstet 1992, 174:302-304.
Publish with Bio Med Central and every scientist can read your work free of charge

"BioMed Central will be the most significant development for disseminating the results of biomedical research in our lifetime. "

Sir Paul Nurse, Cancer Research UK

Your research papers will be:

- available free of charge to the entire biomedical community

- peer reviewed and published immediately upon acceptance

- cited in PubMed and archived on PubMed Central

- yours - you keep the copyright 